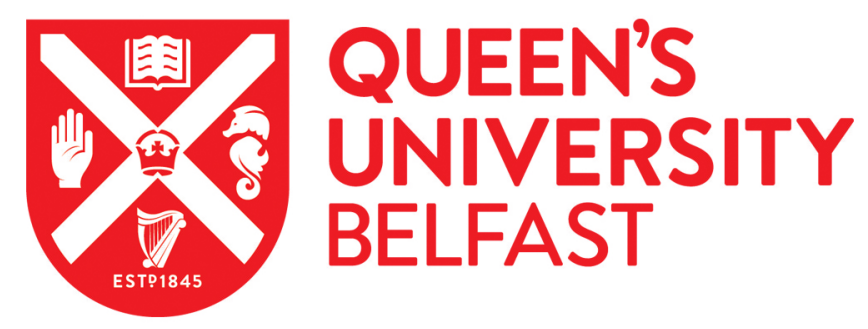

\title{
'The Blazing Torch': New Light on English Balladry as a Multi-Media Matrix
}

Marsh, C. (2015). 'The Blazing Torch': New Light on English Balladry as a Multi-Media Matrix. The Seventeenth Century, 30(1), 95-116. https://doi.org/10.1080/0268117X.2015.1013500

\author{
Published in: \\ The Seventeenth Century
}

Document Version:

Peer reviewed version

Queen's University Belfast - Research Portal:

Link to publication record in Queen's University Belfast Research Portal

Publisher rights

(C) 2015 The Seventeenth Century.

This work is made available online in accordance with the publisher's policies. Please refer to any applicable terms of use of the publisher.

\section{General rights}

Copyright for the publications made accessible via the Queen's University Belfast Research Portal is retained by the author(s) and / or other copyright owners and it is a condition of accessing these publications that users recognise and abide by the legal requirements associated with these rights.

Take down policy

The Research Portal is Queen's institutional repository that provides access to Queen's research output. Every effort has been made to ensure that content in the Research Portal does not infringe any person's rights, or applicable UK laws. If you discover content in the Research Portal that you believe breaches copyright or violates any law, please contact openaccess@qub.ac.uk. 


\section{"The Blazing Torch": New Light on English Balladry as a Multi-Media Matrix}

Author: Christopher Marsh

Affiliation: Professor of Cultural History, Queen's University, Belfast

Address: School of History and Anthropology, 15 University Square, BELFAST, BT7 1NN, Northern Ireland.

E-mail: c.marsh@qub.ac.uk

Tel. 02890683335 (home) and 90973849 (office)

This work was supported by the Arts and Humanities Research Council under Research Grant AH/K003100/1. 
An intriguing hand-written observation appears on the title page of the Roxburghe collection of early-modern broadside ballads. A later owner of the collection, looking back on the composers and consumers of these cheap single-sheet songs, commented admiringly,

their words no shuffling meaning knew, their speech was homely, but their hearts were true. ${ }^{1}$

Ballads, in this individual's opinion, were appealing because they were fundamentally straightforward and honest. Ballad-writers said what they meant and meant what they said, and ballad-consumers must presumably have received their guileless messages loud and clear. Of course, this quaint reading of seventeenth-century literature is hardly in tune with the perspectives developed by scholars in recent decades. In our own age of unsettled texts, ephemeral voices and active audiences, we find no simple or cosy truth in the texts of the past. ${ }^{2}$ Where the Roxburghe collector looked over his shoulder for evidence of a bygone simplicity - ballads were for him an escape from his own duplicitous era - it often seems that scholars, literary specialists in particular, respond to the turbulence of the present by seeking out its echoes and reflections in the past. In other words, it is precisely the "shuffling meaning" inscribed within historical writings that compels the attention.

The term "shuffling meaning" can be taken to incorporate not only the instability of words but also the manner in which the various components of a ballad text, tune, picture (and also performance) - were recycled or "shuffled" into a myriad of combinations. This was a great age of creative regurgitation, and in balladry the individual parts occur again and again in patterned but also constantly shifting 
alliances. During the seventeenth century, a typical ballad-sheet presented to the world a summarising title, a suggested tune (but no musical notation), a text of numerous verses and one or more small woodcut pictures. This sounds simple enough, but the fact that the constituent parts - particularly the pictures and the tunes were often familiar to consumers from their experience of previous ballads must have generated the potential for variable associations and divergent interpretations. Ballad scholarship is moving on apace, but the vast interconnectedness of these printed songs remains seriously under-explored. The literary scholar, Natascha Würzbach, wrote a whole book about ballads but dismissed both tunes and pictures alike because they related to the texts with insufficient precision. ${ }^{3}$ And when historians dip into balladry, they still tend to treat each publication as a self-contained and silent text, rather than a kind of multi-media production (text, tune, pictures, performance) that pulsates with cross-references and associations. The seventeenth century was, after all, an age in which connective thinking was instinctive and highly developed. The world throbbed with correspondences and everything echoed or reflected something else. As the Elizabethan musicologist John Case put it, "things that are of like natures, have mutual \& easy action $\&$ passion betweene themselves. ${ }^{4}$ His point was, of course, more grand and cosmological than the one being made here, but there are good reasons for exploring balladry with Case's comment in mind.

The central argument of this paper can be stated concisely. Ballads should be imagined as part of an enormous interconnected matrix of meanings, incorporating forms of signification that were encoded not only in free-standing verbal texts but in pictures, tunes, performances and the relationships between all of them. Composers and publishers operated instinctively within an evolving system of signification, drawing selectively and creatively upon a wealth of existing resources. They did not 
simply pick out melodies and woodcuts at random but instead deployed both in such a way as to indicate the thematic content of a song and to stimulate sales (the ballad industry was above all a commercial operation). In a partially literate society, the non-verbal components of a ballad were of considerable significance because balladmongers hoped to sell songs to listeners and lookers as well as to readers. And on the other side of the commercial relationship, ballad consumers learned but also shaped the developing system of signification. It was a complex business, for an individual's understanding of a particular song depended upon his or her knowledge of its tune, woodcut and text in previous incarnations, and upon her or his response to the manner in which it was performed. There was scope for each ballad to strike a range of differing chords in the ears of consumers, and the search for a single meaning - a homely truth - within every individual text is therefore futile. Carlo Ginzburg and others have taught us just how active and aggressive early modern reading habits could be, and we can be certain that many ballads were delivered and received as stimulants to debate and dispute rather than as the final word on their chosen themes. ${ }^{5}$

There are numerous obstacles to be faced in the interpretation of ballads. Pitiful survival rates are just the first of these. Ballads are also difficult to date, and therefore hard to place in chronological order. In most cases, ballads were written anonymously and we can only guess at the identity of their authors. Printers borrowed and copied woodcuts from one another, making it difficult to track the careers of particular pictures. Tunes might travel under a variety of different names. It is often difficult to say anything conclusive about the popularity and impact of individual songs. References to the performance and reception of named ballads are extremely thin on the ground. We know that they were sung and sold on the streets, 
bought by passers-by and pinned up at home for future use, but our evidence is characteristically general rather than specific.

These factors are challenging but they need not dissuade us from working to deepen our understanding of this important literary, musical and artistic genre. One fruitful approach might be to identify and give special attention to ballads that are known to have been highly favoured by the most powerful broadside publishers on account of their commercial success. Lists of particularly important ballads were drawn up in 1624,1656 and 1675 by those at the heart of the industry as they attempted to protect their copyrights. ${ }^{6}$ By focusing on such titles and comparing them with others, we can begin to develop a more sophisticated awareness of audience tastes and the relationship between publishers and punters. This paper will make a modest start by attempting to unravel the genealogies and repercussions of two such broadsides, neither of which has attracted significant scholarly attention before now. The various components of these ballads will be carefully considered, and an attempt will be made to track and interpret the many relationships between the chosen songs and others of the period.

The first song appeared on the 1624 publishers' list but was identified only as "Blasinge torch bothe partes." ${ }^{, 7}$ Unfortunately, there was no ballad published under this name, though there was a two-part song entitled $A$ Good Wife, or None with the opening line, "The blazing Torch is soone burnt out." Short-hand ballad names were often generated from the first lines of songs and it therefore seems highly probable that this is the title we seek. Further evidence of its commercial potency can be found in the fact that, despite the ephemerality of the genre, we know that five editions were published between 1624 and 1679. Three copies have survived in total, and one 
leading ballad publisher, William Thackeray, held the song in stock when he compiled his well-known trade list in $1689 .{ }^{8}$

The second broadside was actually two different songs on a single sheet, a sort of double A-side. The publishers' list of 1624 included a clear reference to the ballad that was printed as $A$ Godly New Ballad, Intituled, A Dozen of Points. ${ }^{9}$ During the seventeenth century, there were at least four editions and the ballad survives in four copies. In all cases, $A$ Godly New Ballad was issued with another song, entitled The Angell Gabriel, his Salutation to the Blessed Virgin Mary. Thackeray also listed this title among his stock in $1689 .{ }^{10}$ No melody was ever specified for $A$ Godly New Ballad but The Angell Gabriel was to be sung to the tune of "The Blazing Torch." In other words, our two main broadsides called for the same melody, despite their contrasting subject matter. The implications of this coincidence will emerge as we consider the origins and the inter-twining development of the two publications. ${ }^{11}$

The story begins, however, with yet another ballad. In c.1618, there appeared a song entitled The Faythfull Lovers Resolution, Being Forsaken of a Coy and Faythles Dame, set to the tune of "My deere and only Love take heed" (a hit melody of the period, strongly associated with love). In its first part, a man sings sadly of betrayal by his sweetheart, and resolves that from this point onwards he will live the life of a single man. His wish to "lye alone" forms the song's burden or refrain, sung repeatedly at the conclusion of each verse. The fourth verse, for example, runs,

The blazing Torch is soone burnt out, 
The Diamond light abides,

The first her glory hurles aboute,

The next her vertue hides:

The Sparke if any shall be mine,

That else shewes light to none,

For if to every eye she shine,

Ile rather lye alone.

The second half of the ballad presents "The coy Maydens answere." In fact, she is more curt than coy, telling her whimpering ex-sweetheart to pull himself together and make a new start. She has clearly decided that she can do rather better for herself, and she concludes by reversing the man's sad refrain:

When you are gon there is more Loves,

I will not lye alone. $^{12}$

Little can be said about the success of this song. It was probably not one of the seventeenth century's great hits, and there is only one surviving copy. There are, however, two manuscript versions of the song, both of which take the fourth verse and place it at the top, while omitting the woman's reply. And The Faythfull Lovers Resolution did apparently spawn one of the period's best-selling printed songs, for within a few years of its publication there appeared the first known edition of our featured ballad, A Good Wife, or None, set "To a pleasant new Tune.” Unfortunately, there is no surviving Jacobean copy of the ballad, but versions printed later in the century are available, and the first verse may ring a bell: 
The blazing Torch is soone burnt out,

The Diamonds light abides:

The one in glory shines about,

The other it's virtue hides:

That sparke (if any) shall be mine,

That else gives light to none;

For if to every one she shine,

I had rather lie alone. ${ }^{13}$

The scene-setting introductory verse of this hit song therefore seems to have been lifted, almost word for word, from a stanza in the middle of the earlier ballad. The refrain was also adopted, though the old melody was replaced. We can assume that the "pleasant new tune" was the one that subsequently became known as "Blazing torch." Curiously, neither the melody nor the ballad appear in Claude Simpson's generally impressive encyclopaedia, The British Broadside Ballad and its Music. The tune can be found, however, in a manuscript book of relatively simple music for the virginals that was owned by Anne Cromwell during the 1630s (figure 1). ${ }^{14}$ It has clearly been elaborated somewhat for instrumental performance but it is not difficult to detect the strong melodic line. It is a forthright tune, moving confidently along in common time (with four beats in a bar). In association with the song's repeated declaration, "I had rather lie alone," the melody could even be described as defiant (there is just a touch Gloria Gaynor's "I will survive" about it). Interestingly, the final musical phrase of this "pleasant new tune" was identical to the closing line of "Basse's Careere," another popular melody of exactly 
the same period. ${ }^{15}$ We cannot be sure which of them came into existence first but it seems likely that one tune drew on the other. This relationship, when set alongside the textual similarities between The Faythfull Lovers Resolution and A Good Wife, or None, encourages us to recognise the way in which one ballad might evolve out of another, lifting and resituating various building blocks while laying others to one side. Building blocks were drawn from beyond the world of balladry too, and the title, $A$ Good Wife, or None appears to have been proverbial. ${ }^{16}$ This habit of mixing novelty and tradition, creation and derivation, was clearly instinctive to ballad composers, and many comparable examples could be cited. It was also instinctive to consumers, who were drawn to songs not only by features they recognised but also by those they did not.

The remaining verses of $A$ Good Wife, or None can be related to the ballad that helped to inspire it in other ways too. It further explores the need of the jealous male lover for a woman who will shine for his benefit only. If she does not do so, then he will lie alone. A single life is, in any case, superior because it is free from groans, sighs, female disloyalty and the pains of cuckoldry. In this song, the woman is permitted no right of reply, but the ballad does conclude with a slight softening of the male position. The disgruntled man concedes the possibility that he might one day find a more constant woman and revoke his decision to spend his remaining days in solitude. This common device - a turning over of seemingly firm ground towards the end of a song - seems to have served as a trigger to debate among the members of a mixed audience. The composer and the singer hoped that the instability of the subject position would set tongues wagging and pennies chinking.

For whatever reasons, A Good Wife, or None was both an instant and a lasting success. Other composers were soon attempting to cash in on its popularity by setting 
their own songs to the new "Blazing Torch" melody. Most interestingly, the tune played its part in a Star Chamber case surrounding the abduction, intoxication and forced marriage of a wealthy London widow in 1624. Anne Elsdon, according to those who testified on her behalf, had attempted to repulse the romantic advances of a tobacco-dealer named Tobias Audley. In response, he and a group of disreputable allies summoned her to a tavern and then plied her with strong drink. They kept her in a stupefied state for several days, moving her from tavern to tavern and adding drugs to her cocktail of intoxicants when she continued to show signs of resistance. Eventually, a clandestine wedding ceremony was held in the Nag's Head, Cheapside, presided over by a crooked vicar. Witnesses heard Mistress Elsdon wailing "I will go home" from inside the tavern, but it was instead her new husband who headed for her house and began rifling through its contents. The sordid affair provided part of the material for a theatrical production at the Red Bull - one of Sisson's Lost Plays of Shakespeare's Age - but it also generated a ballad. No printed copy has survived but the ballad's full text is preserved in the Star Chamber records. Cruelly entitled "Keep the widdow wakeing," it was to be sung "To the tune of The blazing torch."

The court case also provides unusual evidence regarding the composition and performance of a Jacobean ballad. It was apparently written by a bookseller named Richard Hodgkins who felt inspired to pick up his pen after witnessing a performance of the play. Deponents reported that, hereafter, the ballad was sung and sold on the streets where, in a nice example of cultural circulation, it also served as an advertisement for the play (explicitly mentioned in the final verse). Near Clerkenwell Cross, a pedlar - described by one deponent as "a lustie fellow, and fit for labour" walked up and down the streets trying to sell copies to passers-by. More controversially, the theatre owner, Aaron Holland, allegedly hired another ballad- 
singer to perform the song right under the window of the abused widow herself. One can only imagine her shame as she heard the singer explain the significance of the expression, "Kepe the widow waking":

Nowe they that rightlie would conceive, the meaning of this phrase,

Marke what ensues, \& then perceive,

The sequell all bewrayes,

The widow being plyed with wyne,

Untill her braynes were akeing,

She married was in such a vaine,

Twas hard to keepe her wakeing.

In this song, we should note that the pre-existing associations of the tune are not only called upon but developed and redirected. The misogyny that was present but understated in the Good Wife ballad is here unrestrained and undiluted. The ballad's subtitle reads, "Lett him that is poore and to wealth would aspire/ Get some old rich widdowe and growe wealthy by her." A woman with a name and a family becomes a mere commodity, and the old refrain - "I had rather lie alone" - is replaced by an aggressive new one, "To keep the widow waking." This refers, of course, to the technical task of ensuring that the widow was sufficiently lucid to utter her marital vows but drunk enough to remain oblivious to the consequences of her words (in the event, it was reported that Widow Elsdon was dribbling at the time of the service and that her jaws were manipulated by some of her suitor's allies). The most obvious message of the song is not that young men should give up on women because of their 
inconstancy but instead that they should feel free to take any woman they want by any means they wish to deploy. ${ }^{17}$

"Keep the widow waking" connects with A Good Wife, or None through its tune and through its new take on the trials-of-courtship theme but it also intersects with other common narrative structures found repeatedly in ballads of the period. It nods, for example, at the stereotype of the lustful and idiotic old widow. ${ }^{18}$ This theme is not developed in detail but consumers would surely have felt their associational antennae twitching at the woman's failure to respond to obvious danger and at her husband's promise that he will make up for his deceit by meeting her sexual needs:

I'll be a comfort all thy life,

At nightes to keepe thee wakeing. ${ }^{19}$

The ballad therefore entangles itself with other songs in numerous ways, and if we had the woodcut pictures that presumably adorned the printed edition, we would probably be able to develop this point further.

Around 1625, the famous ballad-writer Martin Parker shrewdly adopted the "Blazing Torch" tune for one of his own compositions, and there is a single surviving copy in the Pepys Collection. In this instance, we see a master balladeer at work, drawing skilfully upon the popularity and the associations of the tune while simultaneously injecting it with a new dose of satire. In the first half of The Two Welsh Lovers, Parker opens with the common ballad-scenario in which a narrator takes a walk in the fields and overhears another individual, usually wailing mournfully about the agonies of love. The fact that the wailer is in this case a Welshman, one of the stock joke-characters of the period, would presumably have 
encouraged many listeners to attend to the song in mocking mood (though a sympathetic hearing would also have been possible). In Parker's ballad, the lamenting Welshman is a poor shepherd who wrings his hands and weeps apace. He has been undone by a "fatal Nymph," also Welsh, who "did prove the most untrue,/ that ever woman was." Jacobean misogynistic paranoia is again in the air: the nymph assumes a position of power over her sweetheart and commands him in all matters. Then, true to fickle form, she marries a third party when he goes away for a few days, and our whining Welshman draws the obvious conclusion:

It seems by this, 'tis hard to find

A woman true in heart:

Believe them not, though they seem kind,

They can deceive by art.

We men may woe and use the means,

At us they laugh and grin:

Thus we are crost by faithless queens, Which makes me cry Due gwin.

The last line forms the song's refrain and encourages us to laugh. "Duw gwyn," the Welsh for "white God" or "God of purity," appears as an exasperated appeal to the supposedly merciful maker of all things. We are surely being invited to understand this troubled Taff as a figure of fun, somebody who has lost the battle of the sexes and allowed himself to be dominated, deceived and dumped. In the second half of the ballad, however, the ground is stirred again. We are here treated to "the Nymphs Recantation," sung "To the same tune." Now, it is her turn to cry "Due 
gwin" as she realises the error of her ways. She cannot undo what is done, but she can apologise for her abandonment of her sweetheart and, just to set matters straight, enjoy regular sex with him while her husband is out of the house. Thus the ballad's resolution is messy, and a variety of audience reactions - from sympathy to scorn, from approbation to condemnation - seems possible, even encouraged. ${ }^{20}$

The songs considered so far are all variations upon a central theme. They share a focus on courtship, a set of gender prejudices, certain vocabulary and, of course, a catchy melody, yet each twists the existing components in a different way (one of the features of a predominantly oral culture, we are told). ${ }^{21}$ They belong together but they also pull apart. Some ballads pull harder than others, however, and around 1639 the story of the "Blazing Torch" broadsides took what looks at first like a rather unexpected turn. On 22 February, 1639, "A Christmas caroll called the righteous Joseph" was registered with the Stationers' Company in London. ${ }^{22}$ The opening line of one of the two songs on our second featured broadside suggests strongly that the carol thus licenced was The Angel Gabriel, his Salutation to the Blessed Virgin Mary:

When righteous Joseph wedded was

to Israels Hebrew maid,

A glorious Angel came from Heaven, who to the Virgin said:

Hail blessed Mary full of grace, the Lord remains in thee:

Thou shalt conceive and bear a Son, thy Saviour to be. 
There are no surviving copies from this date, but later editions show that this piece of thoroughly traditional Marian devotion was set to the tune of "The Blazing Torch.",23 The text tells us that Mary is mystified to find herself pregnant, and that she therefore leaves home for three months in order to stay with friends,

And then return'd to Joseph back, her Husband meek and mild, Who thought it strange his wife should be Untoucht, thus grown with child.

Joseph shuns Mary for shame, until the Angel appears in the night to reassure him:

For she is purely Maid and Wife, the Mother of Gods own Heir.

Joseph is reconciled to his wife, and Jesus is born. The ballad blends the gospel stories of Matthew and Luke, and it ends by urging us all to praise God for bringing such extraordinary events to pass, "without the help of Man." 24

Several aspects of this ballad savour powerfully of late-medieval, preReformation piety: the essential devotion to Mary; the emphasis upon her triple status as maid, wife and mother (representing a kind of trinity); and the use of a secular melody for a sacred song. Perhaps the publisher was reacting opportunistically to a theological atmosphere dominated by Laudian churchmen who regarded the Virgin Mary with a reverence not shared by their critics. ${ }^{25}$ For our purposes, the most 
intriguing feature of this ballad is the very traditional instinct it reveals for playing around with the nature of the relationship between Mary and Joseph. In late-medieval mystery plays, humour was often generated through the representation of Joseph not only as a righteous man but also as a bumbling fool and a rather special kind of cuckold. ${ }^{26}$ In the ballad, this tendency is perhaps muted in the words, but it was surely drawn out for contemporary audiences by the choice of tune. To knowledgeable ballad-listeners, contemplating this song in 1639 and the years that followed, it must have been very difficult to suppress recollections, whether conscious or unconscious, of a string of other "Blazing Torch" ballads that had appeared in recent years (the manner in which the deleted refrain - "I had rather lie alone" haunts the final line of each new verse in the mind of a singer or listener who also knows the earlier songs is particularly striking). The melody conjured up associations with troubled romantic relationships featuring fickle women and men who were hurt or anguished and in some cases spineless (crying "Due gwin" when they should have been standing up for themselves). And here in the Angel Gabriel, we have Joseph described not only as righteous but also as "meek and mild." These adjectives, traditionally applied to Mary and to other caring mothers, were not in any sense laudatory when attached to a man in seventeenth-century England. The ballad is therefore tapping into a late-medieval tradition of mocking Joseph as the foolish husband of a desirable young wife but it does so by calling upon more recent associations carried by its melody. Of course, we are not being encouraged to think of Mary as a wayward woman but this possibility - carried by the tune - nevertheless complicates the song and contributes to its humour.

As we have seen, The Angel Gabriel was usually issued alongside $A$ Godly New Ballad, Intituled, A Dozen of Points (this had been licensed in 1624 but we must, 
as so often, rely on subsequent editions). ${ }^{27}$ It was a conventional piece of moralising, nicely complementing the Biblical narrative of the other song with some direct advice on godly conduct. We are told to ask God for forgiveness, to praise Him for helping us through every night, to steer clear of Satan, and so on. The long-term success of the song can probably be attributed partly to the device of presenting the twelve pithy aphorisms as "a dozen of Points." A "point" was a piece of advice, but it was also a device designed for securing garments in the age before buttons. As Tessa Watt has noted, travelling chapmen carried points to customers up and down the country, just as they carried ballads. ${ }^{28}$

It is clear that, throughout the years from 1640 to 1690 , our two main broadsides - A Good Wife, or None and A Godly New Ballad with The Angell Gabriel - enjoyed parallel and highly successful existences. Both were major hits, reissued repeatedly and profitable enough to earn places on the lists of best-sellers kept by the leading publishers. It seems likely that, despite or perhaps because of their rather conspicuous differences, they drew associational sparks from one another and contributed to one another's success. The connection between the two was maintained principally by their shared tune, and this tune also linked them to several other songs on closely related themes. Beyond this, the pictures that illustrated successive editions of the two ballads connected them with hundreds of other songs that deployed the same woodcuts. It is to a consideration of these supposedly simple black-and-white images that we shall now turn. ${ }^{29}$

The first known reference to the issue of the Angell Gabriel was recorded in 1639. ${ }^{30}$ Shortly afterwards, the publisher Francis Coles - perhaps reacting to the renewed currency of the "Blazing Torch" tune - produced a fresh edition of $A$ Good Wife, or None. ${ }^{31}$ This is the earliest surviving version, and the three pictures selected 
by Coles or his printer from the existing stock were all among the most frequently recycled woodcuts of the seventeenth century (figure 2). The two images on the right hand side are particularly interesting. There is a notable discrepancy between the confident bearing of the depicted man and the sorry sentiments that are presented in the text. The individual described in the verses has been humiliated yet the man in the woodcut stands boldly with his feet set apart and his arm akimbo. The hand on the hip was strongly associated in this period with masculinity, military prowess and readiness for combat. ${ }^{32}$ As usual, the disjuncture may reflect the fact that the printer had nothing more directly appropriate in his store but it also sets up the possibility of some interesting interpretative tensions. Is this our hero before he became romantically entangled? Is it a picture of what he can become again if he finds true love and a way to settle his seething soul? We might see him as a defiant single man - "I had rather lie alone" - who is either heroic or foolish. On other ballads of the period, he plays a duality of parts: on the one hand, many macho men (lusty suitors, archetypal "good fellows" and a resourceful character stranded in Iceland and driven to eat bears for survival); and on the other, a series of more questionable types (countrymen outwitted by city prostitutes, broken-hearted lovers, gamesters, whoremongers and so on). ${ }^{33}$

This individual was clearly capable of standing alone but here we might also see him as about to embark on some kind of relationship with the lady on the far right. She presumably began her woodcut career as Elizabeth I but by the mid-seventeenth century she had extended her repertoire like a brilliant character actress. Her many ballad appearances also demonstrate that consumers of the period must have been thoroughly attuned to a system of signification in which the details of an illustration were often wildly inappropriate to the subject matter of a song. Presumably, we -as 
viewers - simply filter out the orb and sceptre (barely visible in any case) when we are hearing a song about more humble folk. Alternatively, the long-established reputation of Elizabeth I as the Virgin Queen - the anomalous ruler and repulser of men - is in play behind the scenes. At first glance, she seems to exceed him in confrontational confidence by carrying both arms akimbo (though closer inspection reveals that her hands are not actually on her hips). And where courting or married women are often depicted turning deferentially towards their menfolk, this one looks straight out at us as if she is choosing to ignore the conventions of gender etiquette.

She has attitude, a point that was also developed in other ballads of the midseventeenth century. This woodcut woman also put in appearances as a deceitful prostitute, the wanton concubine of Edward IV and a wilful maiden who rudely rejects an honest suitor. ${ }^{34}$ She also appeared in more exemplary guises but there is little doubting her primary reputation. ${ }^{35}$ When we encounter her on A Good Wife, or None, therefore, we probably think first of her forceful personality and her romantic impenetrability. And if we consider all three of the ballad's pictures together, then perhaps we can detect a narrative sequence: in the woodcut on the far left, the man and the woman are cosily boxed together and each turns slightly towards the other; or the right, in contrast, the two stand apart, and their defiant, outward-facing postures imply, in association with the text, that the relationship is on the rocks ("therefore Ile lie alone").

The next surviving edition of $A$ Good Wife, or None was issued around 1670 and included nineteen minor changes to the text (for some reason, "blazing torch" became "glazing torch" in the opening line). ${ }^{36}$ The woodcuts were overhauled more comprehensively and, again, all four individuals were very well known from dozens of other ballads (figure 3). On this sheet, two pairs of individual pictures present us 
with subtly different possibilities. On the left, we encounter another cocky and confident man who played a variety of roles, most of them admirable, on ballads of the period. He exudes a self-assurance that is sometimes justified and sometimes illadvised. He is simultaneously relaxed and alert, and we should note the sword, the front-facing stance, the widely separated feet, and the extravagant gesture of the left arm. His right hand, like that of his predecessor, is placed firmly on the hip in a gesture of confrontational confidence. ${ }^{37}$ In this ballad, the combat he contemplates is of the romantic variety, and his partner on the left hand side of the sheet is one of the period's most ambivalent females. Where the male figure sometimes appears alone on ballad sheets, this female character - facing sideways with her arm and hand extended - is almost inevitably connected with others. She appears in various guises, but most often either as a lover turning a man away or as lover proving herself receptive to a male advance. ${ }^{38}$ When we see her on a ballad like this one, we do not know quite what to expect. Is she reaching out for him across the divide or is she warning him to stay in his box? Only when we hear or read the song do we find out.

Viewers of this edition were perhaps most likely to understand the left-hand pair of pictures as suggestive of female reluctance or rejection. The right-hand pair, on the other hand, adopted body positions and held reputations that suggested the likelihood of a happy outcome. The purposefully walking man was an extraordinarily regular player on ballads of the seventeenth century, and his reputation was overwhelmingly - though not exclusively - positive. He appeared, for example, as the admirable Sir John Barleycorn and the carefree philosopher on a broadside version of Sir Edward Dyer's poem, "My mind to me a kingdom is." And we meet him twice - on "A Pleasant New Song betwixt a Saylor and his Love." On one side, he prepares to go to sea, and on the other he returns at last to his somewhat disgruntled 
wife (a part played by the ambivalent woman whom we have just encountered). $\mathrm{He}$ has to persuade her to welcome him, and she does so in the end. Most of the time, this man-on-the-move walks amicably towards an acquaintance but on A LookingGlass for a Christian Family he can be seen responsibly turning his back upon the Devil. ${ }^{39}$ He was thus a predominantly positive presence, and when he was called upon to play less seemly roles the publishers sometimes resorted to labelling him in order to ease the disjuncture (on one song, he appears beneath a tag identifying him as "The Rich Miser"). ${ }^{40}$

Back on the c. 1670 edition of $A$ Good Wife, or None, this man's female partner on the right hand side of the ballad was similarly a character whom ballad consumers must, in the main, have come to love. Her body language bears comparison with that of the ambivalent woman on the left but, crucially, the hand of this second female figure is angled downwards, conveying a much less complicated attitude of feminine receptivity. Most frequently, she played the role of the willing female partner - occasionally too willing - on ballads about love. ${ }^{41}$ It is also interesting to note that these two characters appeared together on many ballads other than A Good Wife, or None. The woodcuts were distinct and separate, yet the figures depicted were commonly considered a couple. They seem to have been connected in popular perception, a little like Fred Astaire and Ginger Rogers. They appear together, for example, on Modesty Amazed; Or, The Dorset-shire Damosel Importunate with her Mother to know Rogers Meaning in Wooing - sung "to an excellent new tune" that was to become very popular. Here, in an eye-catching twist, a seated woman takes the part of the maiden's mother and is placed obstructively between the two. In time-honoured fashion, the older woman warns the younger that lustful men are to be tested before they are trusted: 
Dear Daughter that you mayn't miscarry,

Rogers courage never cool,

Till you marry make him tarry,

Pray now take your mother's rule. ${ }^{42}$

Fortunately, it all ends well. Roger convinces the mother that his intentions are good, and wedding and bedding follow in due order.

Several of the ballads upon which these two woodcuts featured were, like $A$ Good Wife, or None, best-sellers. ${ }^{43}$ There can therefore be very little doubt that they enjoyed common currency in seventeenth-century England. On the c.1670 edition of A Good Wife, their appearance could conceivably be read in several different ways. It all depended upon the particular associations that each consumer carried into their interaction with the song. The most common interpretation was probably a hopeful one. The narrator was experiencing romantic disillusionment and sounding off about his intention to "lie alone" but, as he himself admitted at the end, the game was not quite up and a return to the fray could not be ruled out:

For time and opportunity,

Will [win] the coyest Dame,

And overcome the chastest she,

That bears the bravest name:

Yea, Man was made for Womans good,

Not like the idle drone:

But for to heat and stir the blood; 
And not to lie alone. ${ }^{44}$

The seventeenth century's last known edition of $A$ Good Wife, or None appeared during the mid-1670s. It was issued by almost exactly the same alliance of publishers that had produced the previous version but the left-hand pair of pictures was replaced (figure 4). ${ }^{45}$ The change means that the walking man now appears - in subtly different guises - on both sides of the sheet. And the ambivalent woman is replaced by a close cousin who carries a fan. She, like her relative, also generated associations that combined romantic receptivity and resistance. She appeared regularly on ballads as an exemplary lover, keeping herself cool as passion mounted. Yet she also featured repeatedly as a domineering or scolding wife, poised perhaps to deploy her fan as a weapon against her long-suffering husband. In Poor Anthony's Complaint, for example, the resistance implied by her appearance on A Good Wife, or None is rendered more explicit as she scolds and cajoles her husband. Once again, his part is played by the walking man. ${ }^{46}$

It is time now to return to our other main ballad, the double-issue featuring $A$ Godly New Ballad and The Angel Gabriel. These songs were much less "new" in the 1660s than they had been three decades earlier but it is clear that the broadside still matched $A$ Good Wife for popularity. The earliest surviving edition, published around 1660, employs the familiar walking man to illustrate $A$ Godly New Ballad (figure 5). Here, he strides purposefully towards another well-dressed male character, and we imagine him greeting a friend before delivering the wise advice contained in the text. "The gift is small, a dozen of points," he says in the opening lines, "Wherewith I'd wish you knit your joints. ${ }^{, 47}$ It helps that viewers were, by this date, already learning to see the walking man as a fundamentally likeable character. Despite this, his 
presence on this ballad did not last. On the two other surviving editions from the seventeenth century, the egalitarian and secular friendship implied by the first pair of pictures is supplanted by a rather more authoritarian interaction. ${ }^{48}$ Surviving copies from the 1670 s and 1680 s feature two unmistakably godly characters: a sober minister whom we can assume becomes the dispenser of the stern but well-meant moral advice that is contained in the text; and a layman kneeling, as instructed, in prayer, his body angled both upwards towards God and sideways towards his clerical counsellor (figure 6). Versions of this praying man also appeared on other godly ballads of the later seventeenth century, several of them set to the famous gallows tune, "Fortune my foe," under one or other of its alternative names. ${ }^{49}$ It seems likely that the decision to replace one pair of pictures with another indicates an awareness on the part of the publishers that consumers had come to expect that pious songs would carry pious pictures. Not surprisingly, the praying man offered narrower scope for shuffling meanings than many of the other characters we have encountered but we might note that he appeared on broadsheets both as a praiseworthy Protestant and as a devout but misguided Catholic. ${ }^{50}$

There was greater consistency in the pictures chosen to accompany The Angel Gabriel, perhaps because an unequivocally sacred woodcut was chosen at an early date. All surviving copies of the song carry an entirely traditional image of the Madonna and child, attended by two hovering cherubs. ${ }^{51}$ This woodcut would have been familiar to viewers from other pious publications, and it must also have been closely related to some of the pre-Reformation images that could still be seen in a surprising number of churches. Most of these were high up in the stained-glass windows, their inaccessibility having helped them to escape the iconoclasm of the sixteenth century. ${ }^{52}$ Wall-paintings of Mary had not been so lucky and her 
appearance on many ballads of the seventeenth century therefore represented something of a comeback. As Tessa Watt has argued, the migration of images from plaster to paper can tell us a great deal about the powerful instinct for the traditional that existed within post-Reformation piety. ${ }^{53}$

One additional indicator of a song's popularity was its capacity to sustain an existence into later centuries. Our first featured ballad, A Good Wife, or None, does not appear to have passed this particular test, but the two religious ballads very definitely did. Both were named in 1823 on William Hone's list of "Christmas Carols now annually printed." Surviving copies of $A$ Godly New Ballad from the midnineteenth century confirm its currency, though the song had been re-named Twelve Points and adjusted in several small particulars. Its status as a "carol" indicates that it was designed for singing, but it has so far proved impossible to identify the tune. ${ }^{54}$ Copies of The Angel Gabriel, often re-named Righteous Joseph, also survive from the nineteenth century. Interestingly, the publisher of an edition issued in Birmingham during the 1820 s has reduced and re-ordered the text in several ways, and the adjectives "meek and mild," playfully applied to Joseph in the original, are now attached instead to Mary. ${ }^{55}$ The use of these adjectives to describe a heroic Biblical carpenter perhaps seemed inappropriate to later generations, especially in view of the fact that the alternative associations of the tune had apparently been lost by this date with the fading from the repertoire of the anti-romantic ballad that had given the characterisation of Joseph its initial resonance. More than one tune was used for this song in the nineteenth century, and the melody printed in 1833 by William Sandys in his collection of Christmas Carols Ancient and Modern is of particular interest. It is quite clearly a version of the "Blazing Torch" melody from the 1630s, though this later version has acquired a more stately character with the introduction of several 
pauses and the substitution of minim beats for the original crotchets (figure 7). ${ }^{56} \mathrm{We}$ can know little of the tune's two-hundred-year journey but it is a remarkable fact that it retained its identity across the centuries despite being written down only rarely. Quite possibly, the song's place within the developing canon of carols during the eighteenth and nineteenth centuries helps to explain this relative stability.

$* * * * * * * * * * * * * * * * * * * * * * * * * * * * *$

Of course, we can never know for certain how the brains of our early-modern ancestors processed the sights and sounds of balladry, but we can be fairly sure that a capacity for attending to a whole range of "shuffling meanings" played its part. To some extent, this capacity was applied consciously and gave rise to purposeful thoughts and remarks. In a play of 1676, two characters watch a pedlar at work, and one says to the other "Oh Cicely, here's the brave Ballet you and I use to sing. I know it by the picture." ${ }^{" 57}$ Most of the time, however, the search for understanding must have been automatic, drawing upon knowledge that was - in the language of psychologists - "procedural" rather than "declarative." 58 Neuroscientists tell us that the cognitive processing of both music and art involves the automatic storing of data, the learning of the grammar particular to one's culture, the creation of mental templates or schemas against which new or repetitive experiences can be assessed, the generation of expectations based upon our developing knowledge, and the experience of emotion when these expectations are either fulfilled or frustrated. Every region of the brain is involved, and most of us - without even thinking about it - become "expert" listeners and lookers during childhood. ${ }^{59}$ 
The human brain collects, dissects and connects. It must have had a field day when it was set to work on early-modern ballads. Historians and literary scholars tend to concentrate on the texts of ballads, but it is clear that to early modern minds the words were one aspect of a multi-media product that stimulated a multi-sensory response. To attend to a ballad was to experience both the out-there of stimulating sights and the unique combination of in-here and all-around that gives sound its special status. ${ }^{60}$ At the level of the individual consumer, each interaction with a ballad involved the integrated cognitive processing of text, tune, pictures and performance. Each part was measured against memory and attached to relevant recollections. Individuals, often thinking unconsciously, asked themselves a series of questions. Have we heard this before? If we know the tune, what were the themes of the previous ballads for which it was used? Where have we met the pictured characters before and what were they up to? Where is the performer leading us and is it somewhere we wish to go? And how does the ballad's narrative relate to other broadsides that we have seen and heard on comparable themes?

In conclusion, it seems appropriate to highlight the creativity of consumers and the essential variability of ballads. Early modern people, in processing ballads, clearly operated with great flexibility. They were perfectly happy to handle what we might regard as disjuncture between the component parts of a ballad, and they may even have felt stimulated by it. Perhaps incongruities were simply filtered out, or perhaps they helped to make mirth (one ballad features the final moralising words of a dying old man, but the woodcut shows a man who is clearly both healthy and young, his tongue hanging out presumably because he shares his deathbed with an eagerlooking woman). ${ }^{61}$ It is also clear that viewers, encouraged by the combination of a narrative and a melody, continually reinterpreted recurring pictures in order to fit 
them to new ballads. Well-known woodcut characters came back again and again, and it would be interesting to know whether these figures were viewed as familiar and increasingly complex individuals, popping up in various scenes drawn from their imagined lives, or as actors, capable of playing many different parts across careers that lasted for decades. And minds were similarly flexible where tunes were concerned. In written instrumental music of the period, named tunes recur in many variable forms, and the metrical discrepancies between ballads that were set to the same melody suggest that singers must often have reshaped the music in order to accommodate new words. Listeners were clearly not put off by such challenges, and they were adept at recognising old tunes in constantly shifting versions. On another note, we might observe that the creativity of consumers was also fired by the continual mixing of utterly familiar tunes, pictures and tales with those that were described alluringly as "fresh and new."

Commonplace creativity was also revealed in the fascinating but rather mysterious process by which successful ballads were committed to memory and further disseminated, often free from their original physical form. The existence of shortened versions of successful seventeenth-century ballads in some of the period's more expensive songbooks suggests that songs may often have passed into memory in severely reduced and variable forms (in their original versions, some take about 20 minutes to sing). There is, for example, a songbook version of $A$ Good Wife, or None from 1660 that includes five verses rather than the original twelve (significantly, it excludes the eleventh-hour softening of the man's resolve to espouse only celibacy in the future). ${ }^{62}$ As we have seen, nineteenth-century versions of The Angel Gabriel (or Righteous Joseph) were also significantly shorter than the original. 
The composer, the publisher, the printer and the singer of a ballad could hope to guide the responses of consumers, but those responses were ultimately beyond their control. In any case, the composite nature of the production process meant that there were disparate voices at work there too, and we have already noted that ballad authors often seem to have understood the market value of instability. Seventeenth-century broadsides were not in any sense fixed and firm. No two ballads were the same and, arguably, no one ballad was the same twice. These songs, though simple on the surface, are surely to be understood as the strands of a giant, shifting, unstable web of possibilities. Texts, tunes, pictures and performances all played together, continually interweaving and then unravelling again as composers, printers, woodcut artists, singer-sellers and consumers each brought their own variable knowledge to the party. Among consumers, levels of exposure were also highly variable: some merely heard a snatch or caught a glimpse of a ballad as they passed through a marketplace, while others listened attentively, purchased a copy and pinned it up at home for future reading or singing. ${ }^{63}$ The careers of individual illustrations, melodies or lyrics were just as mixed. Some appeared and then disappeared again without striking many chords. Others lasted for decades, even centuries, forging a wealth of connections, like neurons in the brain. Our featured melody, “The Blazing Torch," was just such a survivor. Perhaps it was an "ear worm," the term used by cognitive scientists to describe a tune that lodges in the brain (one wonders whether the common early modern dance title, "maggot," had similar connotations). ${ }^{64}$ Our main melody was certainly built to last, and the carol-singers of Hardy's England used a version that would have been recognisable to those of Milton's age. Clearly, the "Blazing Torch" did not burn out quite so soon, after all. 


\section{Bibliography}

Arber, Edward, ed. A Transcript of the Registers of the Company of Stationers of London, 1554-1640. 5 vols. London: privately printed, 1875-94.

Aston, Margaret. "Bibles to Ballads: Some Pictorial Migrations in the Reformation," in Simon Ditchfield, ed. Christianity and Community in the West: Essays for John Bossy. Aldershot: Ashgate, 2001: 106-30.

Attorney General vs. Audley, National Archives, STAC 8/31/16: fos. 11v, 19v, 47r and 63r-v.

Barlow, Jeremy, ed. The Complete Country Dance Tunes from Playford's Dancing Master. London: Faber Music, 1985.

Barrow, Theodore. “From 'Easter Wedding' to 'The Frantick Lover': the repeated woodcut and its shifting roles," in Kevin D. Murphy and Sally O’Driscoll (eds.), Studies in Ephemera. Text and Image in Eighteenth-Century Print. Lewisburg: Bucknell University Press , 2013: 219-39.

Bloom, Gina. Voice in Motion: Staging Gender, Shaping Sound in Early Modern England. Philadelphia: University of Pennsylvania Press, 2007.

Braddick, Michael J. "Introduction," in Michael J. Braddick, ed. The Politics of Gesture: Historical Perspectives. Oxford: Oxford University Press, 2009: 9-35.

B[ulwer], J[ohn]. Chirologia, or, The naturall language of the hand. London: Tho. Harper, 1644).

Case, John. The Praise of Music. Oxford, 1586. Reprinted New York: Georg Olms Verlag AG, 1980.

Christmas Carols. Birmingham: James Guest, 1834-79.

Cavendish, William. The Triumphant Widow. London: H. Herringman, 1677.

Cooper, Trevor, ed. The Journal of William Dowsing. Woodbridge: Boydell Press, 2001.

Davies, Julian. The Caroline Captivity of the Church: Charles I and the Remoulding of Anglicanism, 1625-1641. Oxford: Clarendon Press, 1992.

Day, W. G., ed. The Pepys Ballads, 5 vols. Woodbridge: D. S, Brewer, 1987.

De Grazia, Margreta, and Peter Stallybrass. "The Materiality of the Shakespearean Text." Shakespeare Quarterly 44, no. 3 (1993): 255-283. 
Dowling, W. G. “Procedural and Declarative Knowledge in Music Cognition and Education," in T. J.

Tighe and W. J. Dowling, eds. Psychology and Music: The Understanding of Melody and Rhythm.

Hillsdale, NJ: Erlbaum, 1993: 5-18.

The Dying Mans Good Counsel to his Children and Friends. London: J. Wright, J. Clarke, W. Thackeray and T. Passinger, 1681-84.

The Essex Man Coozened by a Whore. London: H. Gosson, c. 1631.

An Excellent Ditty, called the Shepherds Wooing Dulcina. London: F. Coles et al., 1674-79.

Eyre, G. E. B., and G. R. Rivington. A Transcript of the Registers of the Worshipful Company of Stationers; From 1640-1708. 3 vols. London: privately printed, 1913-14.

The Faythfull Lovers Resolution. London: P. Birch, c. 1618.

Ferguson, Howard, ed. Anne Cromwell's Virginal Book, 1638. Oxford: Oxford University Press, 1974.

Filipczak, Zirka Z. “Poses and Passions: Mona Lisa's 'Close Folded' Hands,” in Gail Kern Paster, Katherine Rowe and Mary Floyd-Wilson, eds. Reading the Early Modern Passions. Essays in the Cultural History of Emotion. Philadelphia: University of Pennsylvania Press, 2004: 68-88 Foucault, Michel. The Order of Things. London: Tavistock Publications, 1970.

Franklin, Alexandra. "The Art of Illustration in Bodleian Broadside Ballads before 1820." Bodleian Library Record 17, no. 5 (2002): 327-52.

Franklin, Alexandra. "Making Sense of Broadside Ballad Illustrations in the Seventeenth and Eighteenth Centuries," in Kevin D. Murphy and Sally O’Driscoll, eds. Studies in Ephemera. Text and Image in Eighteenth-Century Print. Lewisburg: Bucknell University Press , 2013: 169-93.

A Friends Advice, In an Excellent Ditty. London: imprint cropped, mid-seventeenth century. Fumerton, Patricia. "Remembering by Dismembering: Databases, Archiving, and the Recollection of Seventeenth-Century Broadside Ballads," in Patricia Fumerton and Anita Guerrini, eds. Ballads and Broadsides in Britain, 1500-1800. Farnham: Ashgate, 2010: 13-34.

Ginzburg, Carlo. The Cheese and the Worms: The Cosmos of a Sixteenth-Century Miller. London: Routledge, 1980.

A Godly New Ballad, Intituled, A Dozen of Points and The Angell Gabriel, his Salutation to the Blessed Virgin Mary. London: F. Coles, T. Vere and W. Gilbertson, 1658-64. 
A Godly New Ballad, Intituled, A Dozen of Points and The Angel Gabriel, his Salutation to the Blessed Virgin Mary London: F. Coles, T. Vere, J. Wright and I. Cla[rk], 1674-79.

A Godly New Ballad, Intituled, A Dozen of Points and The Angel Gabriel, his Salutation to the Virgin Mary. London: W. Thackeray and T. Passinger, c. 1685.

Good and True, Fresh and New Christmas Carols. London: F. Coles, 1642.

A Good Wife, or None. London: Francis Coles, c. 1640.

A Good Wife, or None. London: F. Coles, T. Vere and J. Wright, 1663-74.

A Good Wife, or None. London: F. Coles, T. Vere, J. Wright and J. Clarke, 1674-79.

Hamdultun, Valentine. A Merry New Jigge. Or, the Pleasant Wooing Betwixt Kit and Pegge. London:

H. Gosson, c. 1630.

Hone, William. Ancient Mysteries Described. London: printed for the author, 1823.

Houston, R. A. Literacy in Early-Modern Europe: Culture and Education, 1500-1800. London:

Longman, 1988.

Knapp, James A. "The Bastard Art: Woodcut Illustration in Sixteenth-Century England," in Douglas Brooks, ed. Printing and Parenting in Early Modern England. Aldershot: Ashgate, 2005: 151-72.

Knapp, James A. Illustrating the Past in Early Modern England. Aldershot: Ashgate, 2003.

A Lamentable Ballad of the Ladies Fall. London: W. Thackeray and T. Passinger, 1684-86.

The Lamentation of John Musgrave, Who was Executed at Kendal, for Robbing the King's Receiver. London: J. Wright, J. Clark, W. Thackeray and T. Passinger, 1681-84.

Levitin, Daniel. This is your Brain on Music: Understanding a Human Obsession. London: Atlantic Books, 2006.

A Looking-Glass for a Christian Family. London: J. Clarke, W. Thackeray and T. Passinger, 1684-86. A Looking-Glass for All True Christians. London: J. Wright, J. Clarke, W. Thackeray and T. Passinger, 1681-84.

A Looking-Glass for All True Protestants. London: F. Coles, T. Vere, J. Wright and J. Clarke, 1679.

The Lovers Guift, Or a Fairing for Maides. London: John Trundle, c. 1615.

The Loving Virgins Complaint. London: F. Coles, c. 1630.

Luborsky, Ruth Samson. "Connections and Disconnections between images and texts: the case of secular Tudor book illustration." Word and Image 3, no. 1 (1987): 74-85. 
The Married-Womans Case:/ OR/ Good Counsell to Mayds. London: H. Gosson, c. 1625.

A Merry Ballad of a Rich Maid that had 18 Severall Suitors. London: H. Gosson, c. 1620.

A Merry New Song of a Rich Widdowes Wooing. London: T. Langley, c. 1625.

Modesty Amazed; Or, The Dorset-shire Damosel Importunate with her Mother to know Rogers

Meaning in Wooing. London: J. Deacon, 1685-88.

The Nativity/ Righteous Joseph. Birmingham: T. Bloomer, 1821-27.

Negus, Keith. Popular Music in Theory. Cambridge: Polity Press, 1996.

A New Ditty, Shewing the Wonderful Miracles of our Lord Jesus Christ. London: imprint cropped, midseventeenth century.

Ong, Walter J. Orality and Literacy: The Technologizing of the Word. London: Routledge, 1988. The Papist Prayers for Father Peters; OR,/ Their Sad Lamentation for the Downfal of Popery. London: James Bissel, 1689.

"The Pewterers' and Founders' Play," in Englander, David, et al., eds. Culture and Belief in Europe, 1450-1600: An Anthology of Sources. Oxford: Basil Blackwell, 1990).

Phillips, John. Wit and Drollery. London: Nathanial Brook, 1661.

Phillips, Kim M. “Bodily Walls, Windows and Doors: the Politics of Gesture in Late Fifteenth-Century Books for Women," in Jocelyn Wogan-Browne et al., eds. Medieval Women: Texts and Contexts in Late Medieval Britain. Turnhout: Brepols, 2000: 185-98.

A Pleasant New Ballad to Sing Evening and Morn,/Of the Bloody Murther of Sir John Barley-Corn. London: J. Clarke, W. Thackeray and T. Passinger, 1684-86.

A Pleasant New Song Betwixt a Saylor and his Love. London: J. Wright et al., 1681-84.

Poor Anthony's Complaint/ And Lamentation Against his Miseries of/Marriage. London: J. Conyers, $1662-92$

R., M. A President for Young Pen-Men. London: Robert Wilson, 1615.

R., T. The York-shire Maids Fairing: OR, The Forsaken Maids Good Counsel. London: W. Thackeray, T. Passenger and W. Whitwood, 1679-88?

The Rich Mens Joye, Or, The Poor Mens Cares and Comforts. London: J. Back, c. 1688. 
Rollins, Hyder E. An Analytical Index to the Ballad-Entries (1557-1709) in the Registers of the Company of Stationers of London. Chapel Hill: University of North Carolina Press, 1924. Reprinted Hatboro, Pennsylvania: Tradition Press, 1967.

Roodenburg, Herman. “The 'Hand of Friendship': Shaking Hands and Other Gestures in the Dutch Republic," in A Cultural History of Gesture, ed. Jan Bremmer and Herman Roodenburg. Ithaca: Cornell University Press, 1991: 152-78

Roxburghe Ballads. British Library, C20F7-F10.

Sandys, William. Christmas Carols Ancient and Modern. London: Richard Beckley, 1833.

Shimamura, Arthur P. Experiencing Art: In the Brain of the Beholder. Oxford: Oxford University Press, 2013.

Simpson, Claude M. The British Broadside Ballad and its Music. New Brunswick: Rutgers University Press, 1966.

Sisson, C. J. Lost Plays of Shakespeare's Age. Cambridge: Cambridge University Press, 1936.

Smith, Bruce R. The Acoustic World of Early Modern England: Attending to the O-Factor. Chicago: University of Chicago Press, 1999.

Spicer, Joaneath. "The Renaissance Elbow," in Jan Bremmer and Herman Roodenburg, eds. $A$ Cultural History of Gesture. Cambridge: Polity Press, 1991: 84-128.

A Sweet and Pleasant Sonnet, Entituled,/ My Mind to me a Kingdom is. London: M. Coles and associates, $1680-82$.

Tomlinson, Gary. Metaphysical Song. An Essay on Opera. Princeton: Princeton University Press, 1999.

Twelve Points. Birmingham: T. Bloomer, 1821-27.

The Two Constant Lovers,/ OR, A Pattern of True Love. London: W. Thackeray and T. Passinger, 168688.

The Two Welsh Lovers. London: imprint cropped, c. 1625.

V., I. A Letter for a Christian Family. London: J. C., W. T. and T. P., 1684-86.

A Very Pleasant New Ditty. London: H. Gosson, c. 1625.

Waller, Gary. The Virgin Mary in Late-Medieval and Early-Modern English Literature and Popular

Culture. Cambridge: Cambridge University Press, 2011. 
Walter, John. "Gesturing at Authority: Deciphering the Gestural Code of Early Modern England," in Michael J. Braddick, ed. The Politics of Gesture: Historical Perspectives. Oxford: Oxford University Press, 2009: 96-143;

Watt, Tessa. Cheap Print and Popular Piety, 1550-1640. Cambridge: Cambridge University Press, 1991.

Wells, Stanley. Shakespeare and Co. London: Penguin, 2007.

The Woful Lamentation of Mistris Jane Shore. London: J. Clarke, W. Thackeray and T. Passinger, 168486.

A Wonder Beyond Mans Expectation. London: H. Gosson, c. 1632.

Würzbach, Natascha. The Rise of the English Street Ballad, 1550-1630. Cambridge: Cambridge University Press, 1990. 


\section{Figure captions}

Figure 1: "The Blazing Torch," from Ferguson, ed., Anne Cromwell's Virginal Book, 1638, 36.

Figure 2: A Good Wife, or None (Francis Coles, c. 1640)

Figure 3: A Good Wife, or None (Coles, Vere and Wright, 1663-74).

Figure 4: A Good Wife, or None (Coles, Vere, Wright and Clarke, 1674-79).

Figure 5: A Godly New Ballad and The Angel Gabriel (Coles, Vere and Gilbertson, 1658-64).

Figure 6: A Godly New Ballad and The Angel Gabriel (Thackeray and Passinger, c. 1685).

Figure 7: “When Righteous Joseph,” from Sandys, Christmas Carols Ancient and Modern, no. 4. 


\section{Endnotes}

${ }^{1}$ British Library, C20F7-F10, Roxburghe Ballads, vol. 1, title page.
2 De Grazia and Stallybrass, "The Materiality of the Shakespearean Text," 255-283; Bloom, Voice in
Motion, 8; Negus, Popular Music in Theory, ch. 1 .
${ }^{3}$ Würzbach, The Rise of the English Street Ballad, 9 .
${ }^{4}$ Case, The Praise of Music, p. 41 . On cosmological interconnection, see also Foucault, The Order of
Things, 69, and Tomlinson, Metaphysical Song, 9 .
${ }^{5}$ Ginzburg, The Cheese and the Worms, 33. See also Houston, Literacy in Early-Modern Europe, ch. 8.

${ }^{6}$ Arber (ed.), A Transcript of the Registers of the Company of Stationers, vol. 4, 93-4; Eyre and Rivington (eds.), A Transcript of the Registers of the Worshipful Company of Stationers, vol. 2, 36-7 and 496-501.

${ }^{7}$ Arber (ed.), A Transcript of the Registers of the Company of Stationers, vol. 4, 93.

${ }^{8}$ Editions of $A$ Good Wife, or None were issued by the following publishers: Francis Coles (c. 1640); F. Coles, T. Vere and J. Wright (1663-74); and F. Coles, T. Vere, J. Wright and J. Clarke (1674-79). There are two surviving copies of the first of these editions, and one each of the other two. It can also be presumed that further editions, now lost, were issued by the publishers who obtained a licence in the 1620 s and by William Thackeray, who was selling the song in 1689 (a copy of his list can be seen in The Pepys Ballads, vol. 5, 445-54).

${ }^{9}$ Rollins, An Analytical Index to the Ballad-Entries, 60.

${ }^{10}$ Surviving editions of this double-ballad were published as follows: F. Coles, T. Vere and W. Gilbertson (1658-64); F. Coles, T. Vere, J. Wright and I. Cla[rk] (1674-79); W. Thackeray and T. Passinger (c. 1685). There are two extant copies of the last of these, and one each of the other two. Once again, there must also have been an edition in the 1620 s.

${ }^{11}$ Images of the two main broadsides in various editions will be presented in the pages that follow. Where comparison with other ballads is being made, readers who wish to view the originals can do so by consulting either Day, The Pepys Ballads, or the excellent on-line "English Broadside Ballad Archive" at http://ebba.english.ucsb.edu/

12 The Faythfull Lovers Resolution. For the tune, see Simpson, The British Broadside Ballad, 355-57.

${ }^{13} A$ Good Wife, or None (edition issued by Francis Coles, c. 1640).

${ }^{14}$ Ferguson (ed.), Anne Cromwell's Virginal Book, 1638, 36.

${ }^{15}$ This tune can be found in Simpson, The British Broadside Ballad, 37-39.

${ }^{16}$ M. R., A President for Young Pen-Men, G3v.

${ }^{17}$ Attorney General vs. Audley, National Archives, STAC 8/31/16, fos. 11v, 19v, 47r and 63r-v. See also Sisson, Lost Plays of Shakespeare's Age, 80-124, and Stanley Wells, Shakespeare and Co., 124-27.

${ }^{18} \mathrm{See}$, for example, the ballad entitled A Merry New Song of a Rich Widdowes Wooing.

${ }^{19}$ National Archives, STAC 8/31/16, fos. 63r-v.

${ }^{20}$ The Two Welsh Lovers. I am grateful to my mother and her Welsh tutor for translating the expression "Duw gwyn" for me.

${ }^{21}$ Ong, Orality and Literacy, 41-2.

${ }_{22}^{23}$ Rollins, An Analytical Index to the Ballad-Entries, 34.

${ }^{23}$ See, for example, $A$ Godly New Ballad (edition published by F. Coles, T. Vere and W. Gilbertson). ${ }^{24} \mathrm{Ibid}$.

${ }^{25}$ One bishop investigated reports that a group of zealous lecturers had spoken disrespectfully of the Virgin (Davies, The Caroline Captivity of the Church, 154).

${ }^{26}$ See, for example, "The Pewterers' and Founders' Play." For other evidence of attitudes to Mary in post-Reformation England, see Waller, The Virgin Mary.

${ }^{27}$ Rollins, An Analytical Index to the Ballad-Entries, 60.

${ }^{28}$ Watt, Cheap Print and Popular Piety, 250.

${ }^{29}$ Important recent work on woodcuts includes the following: Franklin, "Making Sense of Broadside Ballad Illustrations" and "The Art of Illustration"; Barrow, "From "Easter Wedding' to "The Frantick Lover"'; Luborsky, "Connections and Disconnections between images and texts"; Knapp, Illustrating the Past and "The Bastard Art"; Watt, Cheap Print and Popular Piety; and Aston, "Bibles to Ballads: Some Pictorial Migrations."

${ }^{30}$ Rollins, An Analytical Index to the Ballad-Entries, 34. 
${ }^{31}$ A Good Wife, or None (edition issued by Francis Coles).

${ }^{32}$ Spicer, "The Renaissance Elbow." On early-modern body language, there is much to be learned from B[ulwer], Chirologia, and from a range of more recent writings: Roodenburg, "The 'Hand of Friendship"”; Michael J. Braddick, "Introduction"; Phillips, "Bodily Walls, Windows and Doors"; Walter, "Gesturing at Authority"; and Filipczak, "Poses and Passions."

${ }^{33}$ See, for example: The Lovers Guift; A Very Pleasant New Ditty; A Wonder Beyond Mans Expectation; The Essex Man Coozened by a Whore; A Merry Ballad of a Rich Maid; The Married-Womans Case. ${ }^{34}$ The Essex Man Coozened by a Whore; The Woful Lamentation of Mistris Jane Shore; A Merry New Jigge.

${ }^{35}$ The woodcut represents a wholesome maiden on The Loving Virgins Complaint and The Lovers Guift.

${ }^{36}$ A Good Wife, or None (edition published by F. Coles, T. Vere and J. Wright).

${ }^{37}$ Other ballads featuring this woodcut include A Friends Advice and The Lamentation of John Musgrave.

${ }^{38}$ She can also be seen, for example, on T. R., The York-shire Maids Fairing and A Pleasant New Song Betwixt a Saylor and his Love.

${ }^{39}$ A Pleasant New Ballad to Sing Evening and Morn; A Sweet and Pleasant Sonnet; A Pleasant New Song Betwixt a Saylor and his Love; A Looking-Glass for a Christian Family.

${ }^{40}$ The Rich Mens Joye.

${ }^{41}$ See, for example, An Excellent Ditty, called the Shepherds Wooing Dulcina and A Lamentable Ballad of the Ladies Fall.

${ }^{42}$ Modesty Amazed. The tune for this ballad can be found in Simpson, The British Broadside Ballad, 537.

${ }^{43}$ See, for example, $A$ Lamentable Ballad of the Ladies Fall. There were numerous editions of this ballad and it survives in multiple copies. It was also favoured by the leading ballad publishers (see $n$. $X$, above).

${ }^{44} A$ Good Wife, or None (edition issued by F. Coles, T. Vere and J. Wright).

${ }^{45} \mathrm{~A}$ Good Wife, or None (edition issued by F. Coles, T. Vere, J. Wright and J. Clarke).

${ }^{46}$ An Excellent Ditty; The Two Constant Lovers; Poor Anthony's Complaint.

${ }^{47}$ A Godly New Ballad/The Angell Gabriel (edition published by F. Coles, T. Vere and W. Gilbertson).

${ }^{48} \mathrm{Ibid}$. (editions published first by Coles, Vere, Wright and Clark, and second by W. Thackeray and T. Passinger).

${ }^{49}$ See, for example, $A$ Letter for a Christian Family and A Looking-Glass for All True Christians.

${ }^{50}$ A Looking-Glass for All True Protestants and The Papist Prayers for Father Peters.

${ }^{51}$ A Godly New Ballad/ The Angell Gabriel (all editions).

${ }^{52}$ When William Dowsing sought out "popish pictures" in the churches of East Anglia in 1643-44 he found and ordered the destruction of numerous images of the Virgin Mary, including several "with Christ in her arms" (Dowsing, Journal).

${ }^{53}$ Watt, Cheap Print and Popular Piety, 131-217. The picture can also be seen, for example, on A New Ditty, Shewing the Wonderful Miracles of our Lord Jesus Christ and on the title page of the song-book, Good and True, Fresh and New.

${ }^{54}$ Hone, Ancient Mysteries Described, 97-99; Twelve Points; Christmas Carols.

${ }_{55}^{5}$ The Nativity/Righteous Joseph.

${ }^{56}$ Sandys, Christmas Carols, no. 4.

${ }^{57}$ William Cavendish, The Triumphant Widow (London, 1677), 6-7.

${ }^{58}$ Dowling, "Procedural and Declarative Knowledge," 6.

${ }^{59}$ There are stimulating summaries of recent work in Levitin, This is your Brain on Music and

Shimamura, Experiencing Art.

${ }^{60}$ On the differences between human experience of vision and sound, see Smith, The Acoustic World of Early Modern England, 6-13.

${ }^{61}$ The Dying Mans Good Counsel.

62 Phillips, Wit and Drollery, 24-25.

${ }^{63}$ On the fragmentary experience of balladry, see Fumerton, "Remembering by Dismembering."

${ }^{64}$ Levitin, This is your Brain on Music, 155. There are seventeen "maggots" in the various editions of Playford's Dancing Master. 